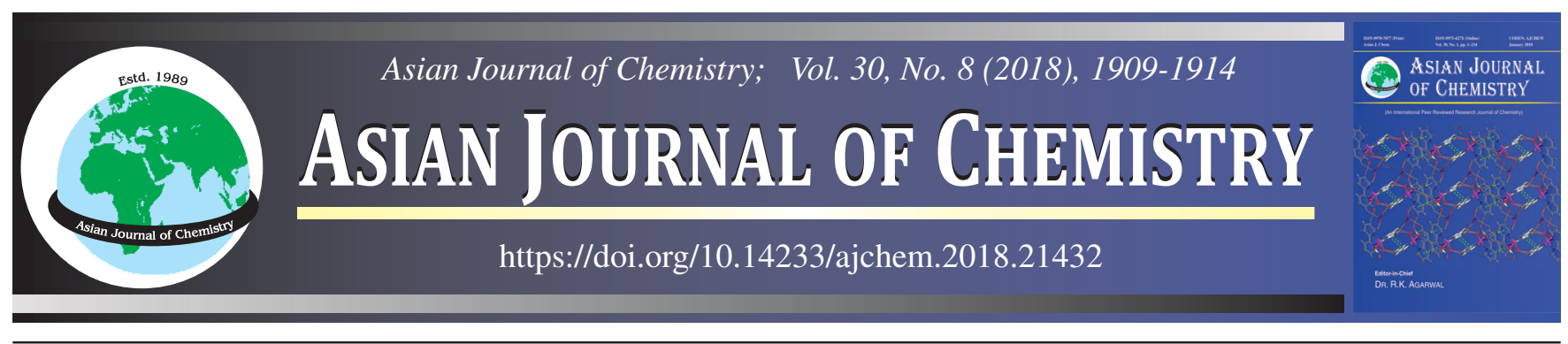

\title{
Green Synthesis, Cyclization and Biological Study of Novel Series of 1,8-Naphthyridines Using Friedlander Condensation
}

\author{
R. NANDHIKUMAR ${ }^{1,2, *}$ and K. SUbramani ${ }^{1,3}$
}

${ }^{1}$ R\&D Centre, Bharathiar University, Coimbatore-641 046, India

${ }^{2}$ Department of Chemistry, The Kavery Engineering College, Mecheri, Salem-636 453, India

${ }^{3}$ PG \& Research Department of Chemistry, Islamiah College, Vaniyambadi-635 752, India

*Corresponding author: E-mail: nandhikumar@gmail.com

Received: 8 May 2018;

Accepted: 4 June 2018;

Published online: 30 June 2018;

AJC-18995

A novel and green synthesis of 1,8-naphthyridines like 2,2,2-trifluoro-1-(2-methyl-1,8-naphthyridin-3-yl)ethanone, 2,2,2-trifluoro-1-(2phenyl-1,8-naphthyridin-3-yl)ethanone, 2-trifluoro-1-(2-phenyl-1,8-naphthyridin-3-yl)ethanone, 1-(2-(4-chlorophenyl)-1,8-naphthyridine3-yl)-2,2,2-trifluoroethanone, 2,2,2-trifluoro-1-(2-(furan-2-yl)-1,8-naphthyridin-3-yl)ethanone and 2,2,2-trifluoro-1-(2-(thiophen-2-yl)1,8-naphthyridin-3-yl)ethanone from ecofriendly and inexpensive $\mathrm{NaH}$ catalyzed Friedlander condensation of 2-aminonicotinaldehyde (1) through carbonyl complexes containing $\alpha$-methylene moiety (2) has been achieved in eco-friendly by microwave irradiation. Elemental analysis, TLC, IR, ${ }^{1} \mathrm{H}$ NMR, ${ }^{13} \mathrm{C}$ NMR and GC-Mass spectroscopy were analyzed the compounds character. The final compounds were tested antimicrobial culture study. In the antibacterial and antifungal study the compounds $\mathbf{3 d}$ and $\mathbf{3 e}$ shows very good activity against Escherichia coli, Pseudomonas aeruginosa and Staphylococcus aureus and $\mathbf{3 b}, \mathbf{3 c}, \mathbf{3 d}, \mathbf{3 e}$ and $\mathbf{3 f}$ shows good action against Penicillium species, Candida albicans and Aspergillus niger, compare to 3a. In this article, a very simple and low-cost method is described for the production of a novel sequence of 1,8-naphthyridines complex and provide very good microbial activity.

Keywords: 2-Aminonicotinaldehyde, Microwave, Antibacterial activity, Antifungal activity.

\section{INTRODUCTION}

Eco-friendly synthetic method is an innovative and promptly emerging of medicinal chemistry fields. Microwaveirradiation synthesis method [1-7] is the best changes in traditional chemical synthetic pathway. By applying the ecofriendly synthetic root [8-10] we can not only avoid the use of hazardous producing substance, toxic solvents but also remove the by-product. Hereafter, they are perfectly agreeable to program for combinatorial synthetic methods.

1,8-Naphthyridine compounds continued to be of great interest due to an extensive spectrum of their microbial activity [11-15] and DNA study [16,17]. Antibiotics moiety of this group is being highly used for the diagnostics and the chemotherapy method of infectious diseases of humans including HIV-AIDS [18]. Several new 1,8-naphthyridine compounds have newly been patented as the growth of herbicides, fungicides, bactericides, regulators, nemathocides and insecticides of new generation and they are also the raw material for many 1,8-naphthyridine compounds $[19,20]$. So their many biological uses $[21,22]$ and employment of these complexes as starting substance for the synthesis of various important heterocyclic of biologically active [23], the growth of effective ways to synthesize these complexes utilizing non-toxic reagents continues to be an active area of research for organic chemists. Ecofriendly $\mathrm{NaH}$ catalyzed [24-26] microwave organic reactions are very important because their special catalytic attributes and inexpensive nature in heterogeneous reactions. $\mathrm{NaH}$ catalyzed Friedlander synthesis of 1,8-naphthyridines under microwave irradiation afforded 1,8-naphthyridines (3a-f) in good yields, remove the pollution issue and take less reaction time.

In this paper, report these methods are simple and highly efficient procedure for microwave-irradiation synthesis of some 1,8-naphthyridine compounds. 1,8-Naphthyridine compounds was assumed by elemental analysis, TLC, IR, ${ }^{1} \mathrm{H}$ NMR, ${ }^{13} \mathrm{C}$ NMR and Mass spectrum. All the final 1,8-naphthyridine compounds study the antibacterial activity against the species of Escherichia coli, Pseudomonas aeruginosa, Staphylococcus aureus and antifungal activity against the species of Penicillium species, Candida albicans and Aspergillus niger, using agar well disk diffusion method. This research paper is very useful for future research communities because pollution free, low cost, easy preparation methods, less time, high yields and good purity. 


\section{EXPERIMENTAL}

Compound melting points of the total outcomes were occupied in an open capillary cylinder and are analyzed. IR spectra (KBR, $v_{\max }$, discs) were taken on Perkin-Elmer 1300 (FTIR) spectrometer and Bruker $\delta(400 \mathrm{MHz}$ FT NMR) spectrometer recorded ${ }^{1} \mathrm{H}$ NMR and ${ }^{13} \mathrm{C}$ NMR (TMS-internal standard), mass spectrum values was recorded on GC-MS spectrometer-Jeol GC mate spectrometer analyzer. All final compounds gave acceptable micro investigative grade report. By TLC methods used to check the final compound's purity.

Synthesis of 2,2,2-trifluoro-1-(2-methyl-1,8-naphthyridin-3-yl)ethanone (3a): To a mixture of 2-aminonicotinaldehyde $(0.01 \mathrm{~mol})$, active methylene compound like $1,1,1,5,5,5$ hexafluoropentane-2,4-dione and $\mathrm{NaH}(0.01 \mathrm{~mol})$ were mixed together without solvent in a $100 \mathrm{~mL}$ conical flask covered with a glass funnel and placed in a microwave oven operating at $500 \mathrm{~W}$ for $2 \mathrm{~min}$ (Table-1). The completion of the reaction was checked by TLC and poured in $50 \mathrm{~mL}$ cool water and normal run with dilute hydrochloric acid (dil. $\mathrm{HCl}$ ). The light yellow solid particle was separated, filtered, dried and recrystallized from acetonitrile. Light yellow solid, m.p. 215$217{ }^{\circ} \mathrm{C}$, yield $82 \%$. IR $\left(\mathrm{KBr}, v_{\max }, \mathrm{cm}^{-1}\right): 3099,3036(\mathrm{Ar}-\mathrm{H}$ cyclic str), 2988, 2931 (C-H str, $\left.\mathrm{CH}_{3}\right), 1688$ (C=O str), 1597, 1577 (C=C str), 1415, 1368 (C=N str), 1314, 1259 (C-C str), 864 (C-F str). ${ }^{1} \mathrm{H}$ NMR (DMSO-H $\mathrm{O}$ ): $\delta$ 9.191-9.204 (1H, d), $8.283(1 \mathrm{H}, \mathrm{s}), 7.728-7.734(1 \mathrm{H}-\mathrm{d})$ 7.299-7.326 (1H, dd), 2.268 $(3 \mathrm{H}, \mathrm{s}) .{ }^{13} \mathrm{C}$ NMR (DMSO- $\left.\mathrm{H}_{2} \mathrm{O}\right): \delta 17.502,115.117,125.705$, $127.612,131.881,134.619,136.342,144.427,151.683$, 165.183, 173.881.CG-MS: $m / z=240 \mathrm{M}^{+}$.

Synthesis of 2,2,2-trifluoro-1-[2-(trifluoromethyl)-1,8naphthyridin-3-yl]ethanone (3b): To a mixture of 2-aminonicotinaldehyde $(0.01 \mathrm{~mol})$, active methylene compound like 1,1,1-trifluoropentane-2,4-dione and $\mathrm{NaH}(0.01 \mathrm{~mol})$ were mixed together without solvent in a $100 \mathrm{~mL}$ conical flask covered with a glass funnel and placed in a microwave oven operating at $500 \mathrm{~W}$ for $2.5 \mathrm{~min}$ (Table-1). The completion of the reaction was checked by TLC and poured in $50 \mathrm{~mL}$ cool water and normal run with dilute hydrochloric acid (dil. $\mathrm{HCl}$ ). The light yellow solid particle was separated, filtered, dried and recrystallized from acetonitrile afforded. Light yellow solid, m.p. $212-215^{\circ} \mathrm{C}$, yield $83 \%$. IR ( $\left.\mathrm{KBr}, v_{\max }, \mathrm{cm}^{-1}\right): 3090$, 3008 (Ar-H cyclic str), 1700 (C=O Str), 1608, $1562(\mathrm{C}=\mathrm{C}$ str), 1530, 1516 (C=N str), 1414, 1473 (C-C str), 1315, 1352 (N-C str), 865, 815 (C-F str). ${ }^{1} \mathrm{H}$ NMR (DMSO-H $2 \mathrm{O}$ ): $\delta 9.352-$ 9.359 (1H, d), $8.180(1 \mathrm{H}, \mathrm{s}), 7.735-7.745(1 \mathrm{H}, \mathrm{d})$ 7.268-7.402 $(1 \mathrm{H}, \mathrm{dd}) .{ }^{13} \mathrm{C}$ NMR (DMSO- $\left.\mathrm{H}_{2} \mathrm{O}\right): \delta 116.005,117.519$, 122.960, 123.058, 129.738, 135.725, 138.646, 147.519, 151.646, 168.097 and 175.392. CG-MS: $m / z=294, \mathbf{M}^{+}$.

Synthesis of 2,2,2-trifluoro-1-(2-phenyl-1,8-naphthyridin-3-yl) ethanone (3c): To a mixture of 2-aminonicotinaldehyde (0.01 mol), active methylene compound like 4,4,4trifluoro-1-phenylbutane-1,3-dione and $\mathrm{NaH}(0.01 \mathrm{~mol})$ were mixed together without solvent in a $100 \mathrm{~mL}$ conical flask covered with a glass funnel and placed in a microwave oven operating at $500 \mathrm{~W}$ for $3.5 \mathrm{~min}$ (Table-1). The completion of the reaction was checked by TLC and poured in $50 \mathrm{~mL}$ cool water and normal run with dilute hydrochloric acid (dil. $\mathrm{HCl}$ ). The light yellow solid particle was separated, filtered, dried and recrystallized from acetonitrile afforded. Light yellow solid, m.p. $295-297^{\circ} \mathrm{C}$, yield $70 \%$. IR ( $\left.\mathrm{KBr}, v_{\max }, \mathrm{cm}^{-1}\right)$ : 3168, 3105 (Ar-H str), 2981, 2900 (C-H, cyclic str), 1669 (C=O Str), 1613, 1577 (C=C str.), 1522, 1463 (C=N, str) 1390, 1366 (CC str), 1285, 1250 (N-C str), 868, 845 (C-F str). ${ }^{1} \mathrm{H}$ NMR $\left(\mathrm{DMSO}-\mathrm{H}_{2} \mathrm{O}\right): \delta$ 9.333-9.383 C-m), 7.515.7.519 (2H, d), 7.422-7.470. $(1 \mathrm{H}, \mathrm{m}) .{ }^{13} \mathrm{C}$ NMR (DMSO-H $\left.2 \mathrm{O}\right): \delta 110.472$, $114.168,115.168,118.278,121.588,125.865,127.065$, $131.108,134.898,138.035,141.198,149.939,151.565$ and 165.254.CG-MS: $m / z=302 \mathrm{M}^{+}$.

Synthesis of 1-[2-(4-chlorophenyl)-1,8-naphthyridin3-yl]-2,2,2-trifluoroethanone (3d): To a mixture of 2-aminonicotinaldehyde $(0.01 \mathrm{~mol})$, active methylene compound like 1-(4-chlorophenyl)-4,4,4-trifluorobutane-1,3-dione and $\mathrm{NaH}$ $(0.01 \mathrm{~mol})$ were mixed together without solvent in a $100 \mathrm{~mL}$ conical flask covered with a glass funnel and placed in a microwave oven operating at $500 \mathrm{~W}$ for $3 \mathrm{~min}$ (Table-1). The completion of the reaction was checked by TLC and poured in $50 \mathrm{~mL}$ cool water and normal run with dilute hydrochloric acid (dil. $\mathrm{HCl}$ ). The light yellow solid particle was separated, filtered, dried and recrystallized from acetonitrile afforded. Light yellow solid, m.p. $335-337^{\circ} \mathrm{C}$, yield $74 \%$. IR ( $\mathrm{KBr}$, $v_{\max }, \mathrm{cm}^{-1}$ ): 3140, 3091 (Ar, C-H str), 2996, 2900 (cyclic, C-H str), 1672 (C=O Str), 1596, 1511 (C=C str), 1462, $1414(\mathrm{C}=\mathrm{N})$, 1370, 1335 (C-C str), 1281, 1269 (C-N str), 869, 833 (C-F, halogen substituted $\mathrm{C}$ str). ${ }^{1} \mathrm{H}$ NMR): (DMSO- $\left.\mathrm{H}_{2} \mathrm{O}\right): \delta 9.084-$ $9.104(1 \mathrm{H}, \mathrm{d}), 8.139(1 \mathrm{H}, \mathrm{s}), 7.521-7.543(1 \mathrm{H} \mathrm{d}), 7.260-7.287$

TABLE- 1

PHYSICAL AND ANALYTICAL DATA OF COMPOUNDS 1,8-NAPHTHYRIDINES COMPOUNDS

\begin{tabular}{|c|c|c|c|c|c|c|c|c|c|c|c|}
\hline \multirow{2}{*}{ Product } & \multirow{2}{*}{ m.f. } & \multirow{2}{*}{$\begin{array}{c}\mathrm{RT}(\mathrm{M}) / \\
\mathrm{T}(\mathrm{W})\end{array}$} & \multirow{2}{*}{$\begin{array}{l}\text { m.p. } \\
\left({ }^{\circ} \mathrm{C}\right)\end{array}$} & \multirow{2}{*}{ m.w. } & \multirow{2}{*}{$\mathrm{R}_{\mathrm{f}}$} & \multicolumn{6}{|c|}{ Elemental analysis (\%): Calcd. (found) } \\
\hline & & & & & & $\mathrm{C}$ & $\mathrm{H}$ & $\mathrm{F}$ & $\mathrm{N}$ & $\mathrm{O}$ & $\mathrm{Cl} / \mathrm{S}$ \\
\hline 3a & $\mathrm{C}_{11} \mathrm{H}_{7} \mathrm{~N}_{2} \mathrm{OF}_{3}$ & $\begin{array}{l}2.0 / \\
500\end{array}$ & $215-217$ & 240 & 0.5 & $\begin{array}{c}52.90 \\
(53.01)\end{array}$ & $\begin{array}{c}2.62 \\
(2.74)\end{array}$ & $\begin{array}{c}22.57 \\
(22.70)\end{array}$ & $\begin{array}{c}10.52 \\
(10.60)\end{array}$ & $\begin{array}{c}6.33 \\
(6.40)\end{array}$ & $\begin{array}{c}0.00 \\
(0.00)\end{array}$ \\
\hline $3 \mathbf{b}$ & $\mathrm{C}_{11} \mathrm{H}_{4} \mathrm{~N}_{2} \mathrm{OF}_{6}$ & $\begin{array}{l}2.5 / \\
500\end{array}$ & $212-215$ & 294 & 0.6 & $\begin{array}{c}41.01 \\
(44.20)\end{array}$ & $\begin{array}{c}1.26 \\
(1.35)\end{array}$ & $\begin{array}{c}38.57 \\
(38.65)\end{array}$ & $\begin{array}{c}9.43 \\
(9.50)\end{array}$ & $\begin{array}{c}5.31 \\
(5.40)\end{array}$ & $\begin{array}{r}0.00 \\
(0.00)\end{array}$ \\
\hline $3 c$ & $\mathrm{C}_{16} \mathrm{H}_{9} \mathrm{~N}_{2} \mathrm{OF}_{3}$ & $\begin{array}{l}3.5 / \\
500\end{array}$ & 295-297 & 302 & 0.6 & $\begin{array}{l}63.26 \\
(6.48)\end{array}$ & $\begin{array}{c}2.92 \\
(3.00)\end{array}$ & $\begin{array}{c}18.73 \\
(18.82)\end{array}$ & $\begin{array}{c}9.12 \\
(9.22)\end{array}$ & $\begin{array}{c}5.15 \\
(5.25)\end{array}$ & $\begin{array}{c}0.00 \\
(0.00)\end{array}$ \\
\hline 3d & $\mathrm{C}_{16} \mathrm{H}_{8} \mathrm{~N}_{2} \mathrm{OClF}_{3}$ & $\begin{array}{l}3.0 / \\
500\end{array}$ & $335-337$ & 336 & 0.5 & $\begin{array}{c}56.91 \\
(57.02)\end{array}$ & $\begin{array}{c}2.23 \\
(2.36)\end{array}$ & $\begin{array}{c}16.82 \\
(16.90)\end{array}$ & $\begin{array}{c}8.22 \\
(8.30)\end{array}$ & $\begin{array}{c}4.62 \\
(4.70)\end{array}$ & $\begin{array}{c}10.48 \\
(10.50)\end{array}$ \\
\hline $3 e$ & $\mathrm{C}_{14} \mathrm{H}_{7} \mathrm{~N}_{2} \mathrm{O}_{2} \mathrm{~F}_{3}$ & $\begin{array}{l}2.0 / \\
500\end{array}$ & 298-301 & 292 & 0.7 & $\begin{array}{c}57.41 \\
(57.52)\end{array}$ & $\begin{array}{c}2.30 \\
(2.40)\end{array}$ & $\begin{array}{c}19.28 \\
(19.45)\end{array}$ & $\begin{array}{c}9.38 \\
(9.55)\end{array}$ & $\begin{array}{c}10.76 \\
(10.92)\end{array}$ & $\begin{array}{c}0.00 \\
(0.00)\end{array}$ \\
\hline $3 f$ & $\mathrm{C}_{14} \mathrm{H}_{7} \mathrm{~N}_{2} \mathrm{OSF}_{3}$ & $\begin{array}{l}4.0 / \\
500\end{array}$ & $356-358$ & 308 & 76 & $\begin{array}{c}54.48 \\
(54.50)\end{array}$ & $\begin{array}{c}2.06 \\
(2.26)\end{array}$ & $\begin{array}{c}18.28 \\
(18.45)\end{array}$ & $\begin{array}{c}8.92 \\
(9.06)\end{array}$ & $\begin{array}{c}5.06 \\
(5.16)\end{array}$ & $\begin{array}{c}10.18 \\
(10.35)\end{array}$ \\
\hline
\end{tabular}


$(2 \mathrm{H}, \mathrm{d}), 7.087-7.139(1 \mathrm{H}, \mathrm{dd}), 6.903-7.055(2 \mathrm{H}, \mathrm{d}) .{ }^{13} \mathrm{C}$ NMR $\left(\mathrm{DMSO}-\mathrm{H}_{2} \mathrm{O}\right): \delta 144.668,118.778,122.288,128.526$, $134.808,136.298,139.305,142.037,145.084,151.640$, 156.397, 164.967 and 169.933. CG-MS: $m / z=336 \mathrm{M}^{+}$.

Synthesis of 2,2,2-trifluoro-1-(2-(furan-2-yl)-1,8naphthyridin-3-yl)ethanone (3e): To a mixture of 2-aminonicotinaldehyde (0.01 mol), active methylene compound like 4,4,4-trifluoro-1-(furan-2-yl)butane-1,3-dione and $\mathrm{NaH}$ (0.01 mol) were mixed together without solvent in a $100 \mathrm{~mL}$ conical flask covered with a glass funnel and located in a marketable microwave oven operating at $500 \mathrm{~W}$ for $2 \mathrm{~min}$ (Table-1). The completion of the reaction was checked by TLC and poured in $50 \mathrm{~mL}$ cool water and normal run with dilute hydrochloric acid (dil. $\mathrm{HCl}$ ). The light yellow solid particle was separated, filtered, dried and recrystallized from acetonitrile afforded. Light yellow solid, m.p. $298-301{ }^{\circ} \mathrm{C}$, yield $80 \%$. IR ( $\mathrm{KBr}$, $\left.v_{\max }, \mathrm{cm}^{-1}\right): 3097,2979$ (cyclic, C-H str), 2936, 2900 (C-H Five membered ring str), 1669 ( $\mathrm{C}=\mathrm{O}$ Str), 1573, $1465(\mathrm{C}=\mathrm{C}$ str), 1423, $1370(\mathrm{C}=\mathrm{N}), 1327,1283$ (C-C str), 1263, 1194 (C$\mathrm{N}$ str.), 1027 (C-O str), 868, 836 (C-F str). ${ }^{1} \mathrm{H}$ NMR (DMSO$\left.\mathrm{H}_{2} \mathrm{O}\right): \delta 9.511-9.519(1 \mathrm{H}, \mathrm{d}) 8.864(1 \mathrm{H}, \mathrm{s}), 8.256-8.263(1 \mathrm{H}$, d), 7.422-7.517 (1H, dd), 7.013-7.350 (1H, d), 6.660-6.83 $(2 \mathrm{H}$, d). ${ }^{13} \mathrm{C}$ NMR (DMSO- $\mathrm{H}_{2} \mathrm{O}$ ): $\delta$ 100.758, 103.858, 118.088, 126.252, 127.526, 128.303, 134.472, 137.068, 138.168, 144.950, 151.640, 154.940, 165.106 and 171.871. CG-MS: $m / z=292 \mathrm{M}^{+}$.

Synthesis of 2,2,2-trifluoro-1-(2-(thiophen-2-yl)-1,8naphthyridin-3-yl) ethanone (3f): To a mixture of 2-aminonicotinaldehyde $(0.01 \mathrm{~mol})$, active methylene compound like 4,4,4-trifluoro-1-(thiophen-2-yl)butane-1,3-dione and $\mathrm{NaH}$ $(0.01 \mathrm{~mol})$ were mixed together without solvent in a $100 \mathrm{~mL}$ conical flask covered with a glass funnel and located in a marketable microwave oven operating at $500 \mathrm{~W}$ for $4 \mathrm{~min}$ (Table-1). The completion of the reaction was checked by TLC and poured in $50 \mathrm{~mL}$ cool water and normal run with dilute hydrochloric acid (dil. $\mathrm{HCl}$ ). The light yellow solid particle was separated, filtered, dried and recrystallized from acetonitrile afforded. Light yellow solid, m.p. $356-358^{\circ} \mathrm{C}$ yield $76 \%$. IR (KBr, $\left.v_{\max }, \mathrm{cm}^{-1}\right): 3117,3029$ (cyclic C-H str), 2977, 2810 (thiophene $\mathrm{C}-\mathrm{H}$ str), 1679 (C=O Str), 2066 (overtone), 1525, 1456 (C=C str), 1383, 1365 (C=N str), 1343, 1314 (CC str), 1219,1187 (N-C, str), 1091 (C-S, str), 866 (C-F str). ${ }^{1} \mathrm{H}$ NMR (DMSO- $\left.\mathrm{H}_{2} \mathrm{O}\right): \delta 9.519-9.619(1 \mathrm{H}, \mathrm{d}), 9.124(1 \mathrm{H}, \mathrm{s})$, 8.356-8.363 (1H, d), 7.682-7.787 (1H, dd), 7.253-7.305 (1H, d), 6.910-6.953 (2H, d). ${ }^{13} \mathrm{C}$ NMR (DMSO- $\left.\mathrm{H}_{2} \mathrm{O}\right): \delta 114.960$, 117.808, 120.252, 123.726, 127.171, 132.660, 133.199, $137.307,141.508,148.226,150.903,156.708,165.297$ and 171.637. CG-MS: $m / z=308 \mathrm{M}^{+}$.

\section{RESULTS AND DISCUSSION}

Microwave synthesized 3a-f compounds were prepared by 2 -aminonicotinaldehyde and the active methylene compound was mixed with $\mathrm{NaH}$ was subjected to microwave at 500 W (Scheme-I).

Based on the data was labelled in Table-1. The reaction is fresh and effective. The products are obtained in very good yields and in a state of high purity. The process is eco-friendly benign. The experimental technique is very simple.

In a typical research, an equimolar mixture of 2-aminonicotinaldehyde $(\mathbf{1})$ and active methylene compound $\mathbf{2}(\mathrm{R}=$ $\mathrm{CH}_{3} ; \mathrm{R}_{1}=\mathrm{CF}_{3}$ ) was mixed with $\mathrm{NaH}$ and the reaction combination was shown to microwave synthesis at $500 \mathrm{~W}$ for 2.0 min. Later normal work-up 2,2,2-trifluoro-1-(2-methyl1,8-naphthyridin-3-yl) ethanone (3a) $\left(\mathrm{R}=\mathrm{CH}_{3} ; \mathrm{R}_{1}=\mathrm{CF}_{3}\right)$ was obtained in $82 \%$ yield. To know the role of microwave synthesis in rate improvement for the Fridlander condensation reaction, parallel reaction were carried out in are flex oil-bath for $2.5 \mathrm{~h}$ at $100-120^{\circ} \mathrm{C}$, where the reaction process took longer time for end giving the product in very poor yields [2,27] (Fig. 1 ). It is noted that the 1,8-napthyridines synthesis under microwave method is very good compare to the normal methods.

The formation of 2,2,2-trifluoro-1-(2-methyl-1,8-naphthyridin-3-yl) ethanone (3a) was confirmed by the presence of aromatic cyclic peaks at $3099,3036, \mathrm{C}=\mathrm{N}$ is stretching peaks

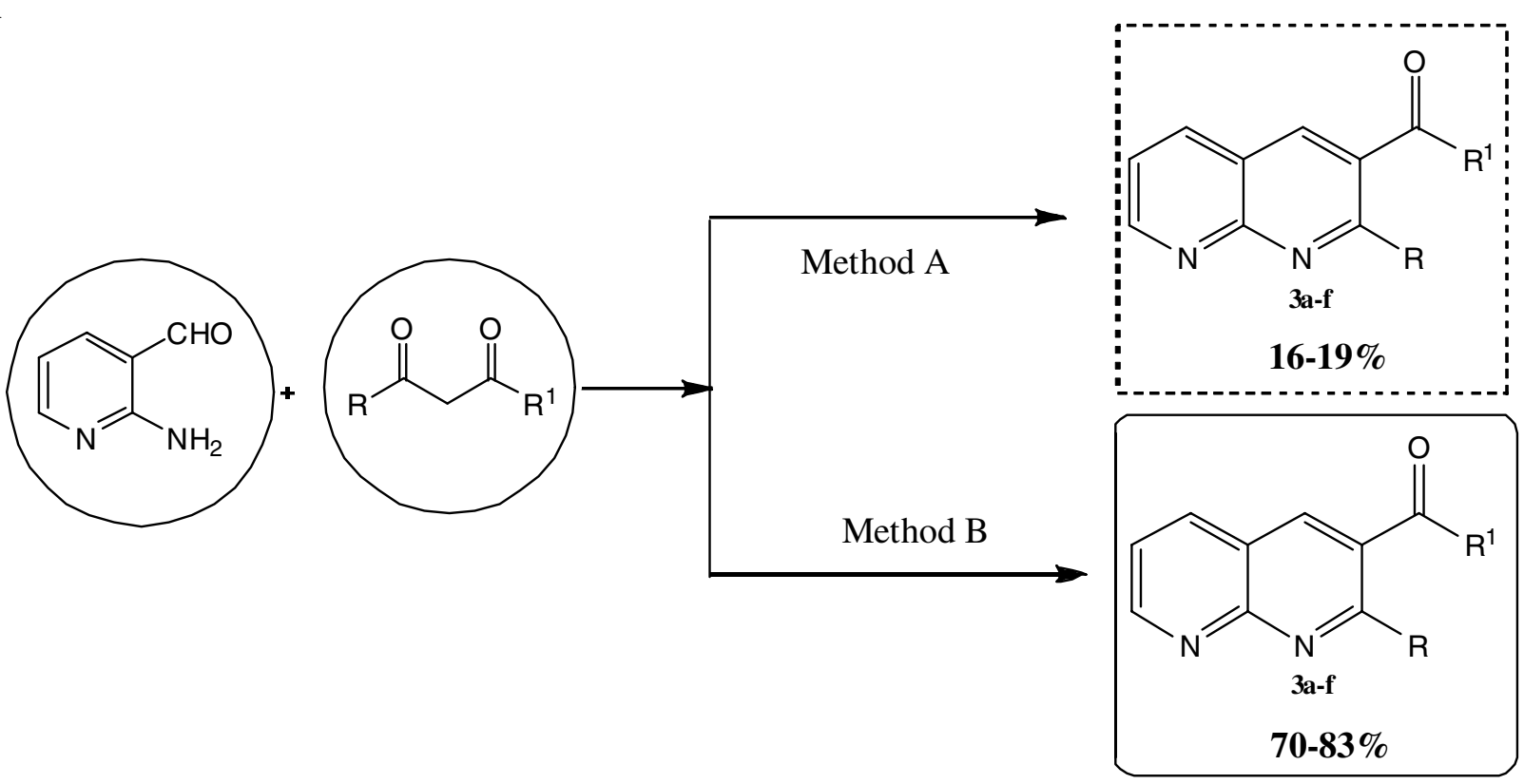

Fig. 1. Comparison synthesis of 1,8-napthyridines compounds using reflux (Method A) and microwave irradiation (Method B) 
<smiles>Nc1ncccc1C=O</smiles>

1<smiles>[R]C(=O)CC([R])=O</smiles><smiles>[Mg][Mg][Mg][Mg]</smiles><smiles>[R]c1nc2ncccc2cc1C(=O)CC</smiles>

\section{Active methylene compounds}<smiles>CC(=O)CC(=O)C(F)(F)C(=O)CC(=O)C(F)(F)C(=O)CC(=O)C(=O)CC(=O)C(F)(F)F</smiles><smiles>Cc1nc2ncccc2cc1C(=O)O[Ga]O[Mg]</smiles>

Scheme-I

at $1415,1368, \mathrm{C}=\mathrm{O}$ peaks at $1688, \mathrm{CH}_{3}$ peaks at 2988,3036 and C-F peaks at $864 \mathrm{~cm}^{-1}$ in IR and singlet at $(1 \mathrm{H}) 8.283 \delta$ for 1,8-naphthyridin group in ${ }^{1} \mathrm{H}$ NMR spectra.

${ }^{13} \mathrm{C}$ NMR spectrum and mass spectrum also supported the proposed structure and viewing molecular ion peak at $\mathrm{m} / \mathrm{z}$ $=240 \mathrm{M}^{+}$. Similarly, remaining 1,8-naphthyridin compounds 3b-3f was obtained the IR, ${ }^{1} \mathrm{H}$ NMR, ${ }^{13} \mathrm{C}$ NMR and GC-MS values at nearer the compound $\mathbf{3 a}$.
The mechanism of microwave synthesis of 1,8-naphthyridines [28] is given in Fig. 2. Fig. 2 explains that 2-aminonicotinaldehyde group containing two functional groups like aldehyde and amine groups, but the aldehyde group contains $\mathrm{C}=\mathrm{O}$ group so this group first attack of an active methylene carbonyl group and then react to the amine group finally cyclization occur with elimination water molecule to produce novel 1,8-naphthyridines series. 


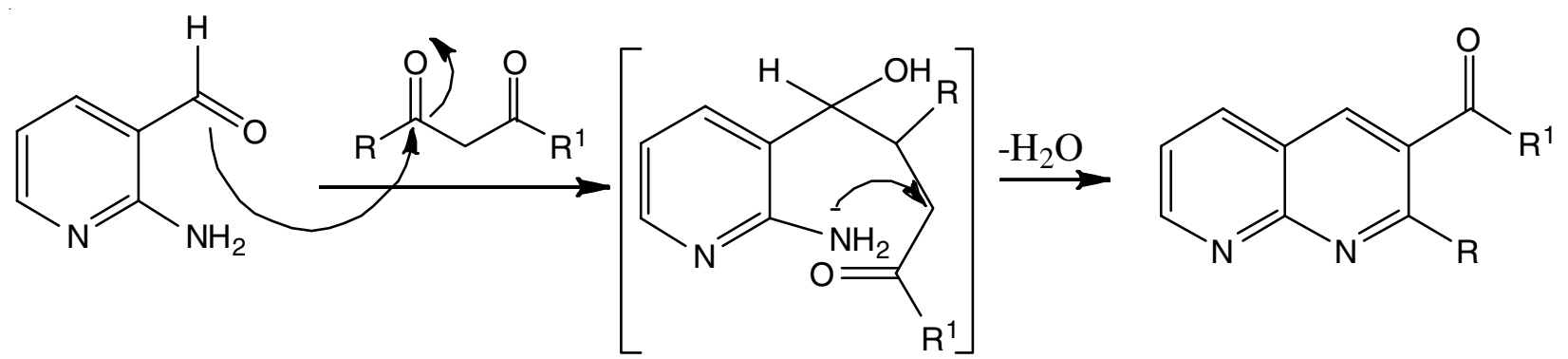

Fig. 2. Mechanism of 1,8-napthyridines compounds

Antibacterial activity: Novel synthesized 1,8-naphthyridines compounds are selected for their antibacterial study in vitro beside the species of Escherichia coli (Gram-negative), Pseudomonas aeruginosa (Gram-negative) and Staphylococcus aureus (Gram-positive) through agar well disk dispersion technique. Ciprofloxacin is used as a standard drug and the outcomes are shown in Table-2, Fig. 3. In the antibacterial study the compounds $\mathbf{3 d}$ and $\mathbf{3 e}$ shows very high activity against Escherichia coli, Pseudomonas aeruginosa and Staphylococcus aureus compare to other 1,8-naphthyridines compounds.

Antifungal activity: Recently synthesized 1,8-naphthyridines compounds are separated for their antifungal study in vitro beside the species of Aspergillus niger, Penicillium species and Candida albicans, by agar well disk dispersion technique. All 1,8-naphthyridines compounds are dissolved in DMSO. Amphotericin-B is used as a normal and the outcomes are exposed in Table- 2 and Fig. 3. In the anti-fungal study the compounds $\mathbf{3 b}, \mathbf{3 c}, \mathbf{3 d}, \mathbf{3 e}$ and $\mathbf{3 f}$ shows very good activity against Aspergillus niger, Penicillium species, Candida albicans, compare to 3a.

\section{Conclusion}

In conclusion, the microwave irradiated Friedlander synthesis catalyzed by $\mathrm{NaH}$ reported in this research is a suitable method for the synthesis of 1,8-napthyridines compounds in very good yield and outstanding cleanliness. Advantages such as use of low-cost catalyst that can be easily divided and recycled, very simple experimental setup and easy work up protocols and a very small reaction process time, creates our preparation method a very use full and smart synthetic procedure methods for the 1,8-naphthyridines compounds.

Total compounds are lively against all the bacterial and fungal strains. 1,8-Naphthyridines compounds are more active against antibacterial and fungal strains for standard drug for antibacterial activity. In the antibacterial and antifungal study the compounds $\mathbf{3 d}$ and $\mathbf{3 e}$ shows very good activity beside Escherichia coli, Pseudomonas aeruginosa and Staphylococcus

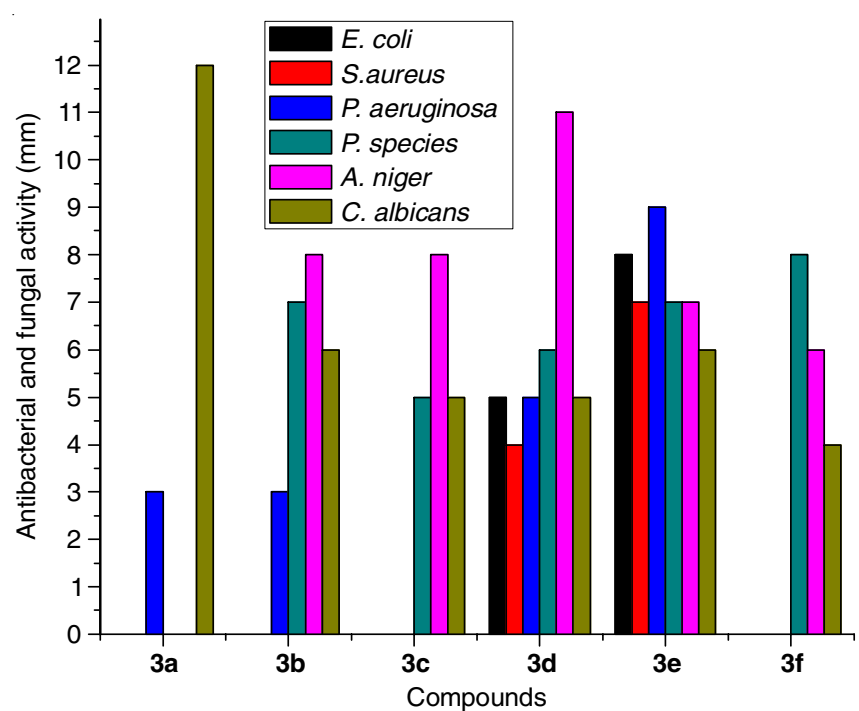

Fig. 3. Comparison of antimicrobial activity for 1,8-naphthyridines compounds

aureus and $\mathbf{3 b}, \mathbf{3 c}, \mathbf{3 d}, \mathbf{3 e}$ and $\mathbf{3 f}$ displays very good activity against Aspergillus niger, Penicillium species and Candida albicans, compare to $\mathbf{3 a}$.

\section{ACKNOWLEDGEMENTS}

The authors are thankful to Principal and Head of Department of Chemistry, Islamiah College Vaniyambadi, India and Dr. G. Sarawathi, Head of Department of Chemistry Government Engineering College, Bargur, India for providing necessary research facilities and spectral data.

\section{REFERENCES}

1. B.L. Hayes, Aldrichimica Acta, 37, 66 (2004).

2. B.M. Sahoo, J. Appl. Pharm., 8, e106 (2016); https://doi.org/10.4172/1920-4159.1000e106.

3. V. Polshettiwar, M.N. Nadagouda and R.S. Varma, Aust. J. Chem., 62, 16 (2009); https://doi.org/10.1071/CH08404

TABLE-2

ANTIBACTERIAL ACTIVITY AND ANTIFUNGAL ACTIVITY FOR 1,8-NAPHTHYRIDINES (3a-f)

\begin{tabular}{|c|c|c|c|c|c|c|}
\hline \multirow{2}{*}{ Compounds } & \multicolumn{3}{|c|}{ Antibacterial activity (mm) } & \multicolumn{3}{|c|}{ Antifungal activity (mm) } \\
\hline & E. coli & S. aureus & P. aeruginosa & P. species & A. niger & C. albicans \\
\hline $3 \mathbf{a}$ & - & - & 3 & - & - & 12 \\
\hline $3 \mathbf{b}$ & - & - & 3 & 7 & 8 & 6 \\
\hline $3 c$ & - & - & - & 5 & 8 & 5 \\
\hline 3d & 5 & 4 & 5 & 6 & 11 & 5 \\
\hline $3 e$ & 8 & 7 & 9 & 7 & 7 & 6 \\
\hline 3f & - & - & - & 8 & 6 & 4 \\
\hline
\end{tabular}


4. C.O. Kappe, Chimia, 60, 308 (2006); https://doi.org/10.2533/000942906777836273.

5. P. Lidström, J. Tierney, B. Wathey and J. Westman, Tetrahedron, 57, 9225 (2001); https://doi.org/10.1016/S0040-4020(01)00906-1.

6. P. Acosta, E. Butassi, B. Insuasty, A. Ortiz, R. Abonia, S. Zacchino and J. Quiroga, Molecules, 20, 8499 (2015); https://doi.org/10.3390/molecules20058499.

7. B. Ondruschka, and W. Bonrath, Chimia, 60, 326 (2006); https://doi.org/10.2533/000942906777836246.

8. S. Caddick, Tetrahedron, 51, 10403 (1995); https://doi.org/10.1016/0040-4020(95)00662-R.

9. R.S. Varma, Green Chem., 1, 43 (1999); https://doi.org/10.1039/a808223e.

10. P. Lidstrom, J. Tierney, B. Wathey and J. Westman, Tetrahedron, 57, 9225 (2001); https://doi.org/10.1016/S0040-4020(01)00906-1.

11. J.T. Leonard, R. Gangadhar, S.K. Gnanasam, S. Ramachandran, M. Saravanan and S.K. Sridhar, Biol. Pharm. Bull., 25, 798 (2002).

12. I.P. Singh, S. Kumar and S. Gupta, Med. Chem., 13, 430 (2017); https://doi.org/10.2174/1573406412666161228112127.

13. R.A. Mekheimer, A.M. Abdel Hameed and K.U. Sadek, ARKIVOC, 269 (2007); https://doi.org/10.3998/ark.5550190.0008.d30.

14. K. Mogilaiah, G. Ramasudhakar and N.V. Reddy, Indian J. Chem., 42B, 1753 (2003)

15. D. Ramesh, M.T. Chary, E. Laxminarayana and B. Sreenivasuli, Indian J. Chem., 49B, 1271 (2010).

16. T.R. Ravikumar Naik, H.S. Bhojya Naik, M. Raghavendra and S. G.K. Naik, ARKIVOC, 15, 84 (2006); https://doi.org/10.3998/ark.5550190.0007.f11.
17. T.R. Ravikumar Naik, H.S. Bhojya Naik, H.R. Prakash Naik, P.J. Bindu, B.G. Harish and V. Krishna, Med. Chem., 5, 5 (2009); https://doi.org/10.2174/157340609789117804.

18. N.S. Ahmed, K.O. AlFooty and S.S. Khalifah, J. Chem., Article ID 126323 (2014); https://doi.org/10.1155/2014/126323.

19. S. Abu-Melha, Acta Chim. Slov., 64, 919 (2017); https://doi.org/10.17344/acsi.2017.3617.

20. R. Álvarez-Manzo, J. Mendoza-Canales, S. Castillo-Cervantes and J. Marín-Cruz, J. Mex. Chem. Soc., 57, 30 (2013); https://doi.org/10.29356/imcs.v57i1.234.

21. E.B. Jahromi and A. Mehranpour, J. Hetrocycl. Chem., 54, 1210 (2017); https://doi.org/10.1002/jhet.2694.

22. A. Madaan, R. Verma, V. Kumar, A.T. Singh, S.K. Jain and M. Jaggi, Arch. Pharm., 348, 837 (2015); https://doi.org/10.1002/ardp.201500237.

23. S.M. Behalo and G. Mele, J. Hetrocycl. Chem., 54, 295 (2017); https://doi.org/10.1002/ihet.2581.

24. R. Rajkumar, K. Saravanamani and S.P. Rajendran, J. Chem. Pharm. Sci., 10, 307 (2017)

25. A. Corsaro, U. Chiacchio, V. Pistara and G. Romeo, Curr. Org. Chem., 8, 511 (2004); https://doi.org/10.2174/1385272043485828.

26. M. Shmidt, A. Reverdito, L. Kremenchuzky, I. Perillo and M. Blanco, Molecules, 13, 831 (2008); https://doi.org/10.3390/molecules13040831.

27. K. Mogilaiah and J.U. Rani, Indian J. Chem., 45B, 1051 (2006).

28. J. Marco-Contelles, E. Pérez-Mayoral, A. Samadi, M. do Carmo Carreiras and E. Soriano, Chem. Rev., 109, 2652 (2009); https://doi.org/10.1021/cr800482c. 